\title{
Income Preferences and Household Savings ${ }^{1}$
}

\section{Introduction}

According to the standard theory, savings are chiefly determined by one's consumption profile ("consumption smoothing") as well as the growth and level of income under income uncertainty. Saving theories stemming from theoretical backgrounds such as the Keynesian concepts of the propensity to consume and propensity to save [Keynes, 1936], the life cycle hypothesis [Modigliani, 1954], and the permanent income theory [Friedman, 1957], have been expanded. New ideas of buffer stock saving [Carroll, 1997], the precautionary motive, liquidity constraints [Campbell, 1987], [Deaton, 1991], bequest motive [Kotlikoff, 1989], and behavioral features [Katona, 1975], [Warneryd, 1999] have appeared.

The level of personal/household disposable income and its growth is one of the main determinants of savings. In the life-cycle/permanent income theories, the saving rate depends on the expected length of retirement and the diversion of current income from the life-cycle/permanent income. The macroeconomic saving rate increases with the growth of the economy due to population growth and productivity growth. According to the permanent income theory, expectations of an increase of income in the future will lead to a fall in savings (income effect). According to the life-cycle theory, savings may rise when income is expected to grow because the income effect may be leveled up by productivity growth.

However, in theoretical and empirical literature concerning household income, there is evidence of excessive sensitivity and consumption of current disposable income [Flavin, 1981], [Baxter, Jermann 1999]. This is due to the fact that at least half of all consumers are not forward looking and they do not smooth consumption in the long run throughout their life cycle. Consumption responds to the uncertainty in current and future incomes. Consumers with greater income uncertainty would consume less while saving more [Carroll, 1994]. Savings react mainly to those expected changes of current income that alter permanent household income. The impact of unexpected changes in current income on savings is unpredictable [Liberda, Górecki, Pęczkowski, 2004].

Expectations of preferred income are an outcome of economic conditions and family needs as well as factors such as the number and age of children, age

\footnotetext{
The author works at the Warsaw University Department of Economic Sciences.

1 An earlier version of this paper was presented at the Congress of the International Association for Research in Economic Psychology (IAREP) and the Society for the Advancement of Behavioral Economics (SABE), Paris, July 5-8, 2006.
} 
of adults in the household, and the costs of living in a certain area. But income preferences are also determined by an individual's psychological features and behavior. There are difficulties involved in attempts to measure behavior.

The behavioral approach to saving draws on the psychological motives for saving formulated by Keynes in 1936. According to Keynes, people save in order to build up reserves; to provide for anticipated expenditures in future; to enjoy interest and appreciation on account of increased consumption; to be independent; to carry out business; to bequeath a fortune; and "for pure miserliness."

Behavioral economists and economic psychologists analyze the psychological sources of the basic assumptions of economic theory such as rationality, selfishness and the unchanging tastes of an economic agent [Kahneman, 2003], [Lea, Tarpy, Webley, 1987], [Tyszka, 2004]. In psychological economics, new theories have been developed incorporating elements of behavior into standard economic models. Among the best known are the prospect theory of risky choice by Kahneman and Tversky [1979], myopic loss aversion [Benartzi, Thaler, 1995], and quasi-hyperbolic discounting [Laibson, 1997].

Economic theory is blended with empirical psychology in the measurement of expectations and subjective valuation of income [Katona, 1975], and in the analysis of fertility and family size [Becker, 1976], altruism [Kotlikoff, 1989], [Stark, Wang, Wang, 2005], and life-cycle happiness [Easterlin, 2006].

In the area of saving and consumption, the psychological approach does not challenge the basic assumption of the life-cycle model that people make rational inter-temporal plans. This approach rather describes empirically how people actually behave in an uncertain world. For example, consumers who are hyperbolic discounters make choices of their inter-temporal consumption depending on their current income, while standard life-cycle consumers rank consumption independently of their current income.

Though consumption is heavily discounted when related to the state of affairs today, hyperbolically discounting consumers discount the very distant future ("after tomorrow") relatively less when it is related to the near future ("tomorrow"). They are ready to sign up for long-term contractual savings provided they start tomorrow, even if the rate of contribution (deduction of salary) is planned to increase up to a certain target level [Thaler, Benartzi, 2004]. Behavioral models also incorporate such elements of behavior as cognitive variables (self-control, computational power, and so on) into the standard economic model.

In this paper, the author attempts to measure preferences concerning household income. The paper deals with the preferred level of income that, according to the perception of the household head, would fulfill the needs of the family at a "good," "sufficient" or "insufficient" level. We then analyze the relationship between subjectively preferred income and household savings. Emphasis is placed on differences in income preferences between men and women as household heads and the age of the household head. 


\section{Income preferences of households}

The empirical analysis is conducted on the basis of data from Household Budget Surveys for Poland in 2004. The sample consists of 32,000 households. The variable used in the analysis of household behavior is the subjectively preferred level of income as perceived by the household head.

There are four variables of preferred income, according to a Central Statistical Office (GUS) survey in which respondents were asked about the level of income that they considered "hardly sufficient," "sufficient," "good" or "very good" for their household's needs. These variables are measured in absolute income units. For the purpose of this paper, the current disposable incomes of households have been ranked into groups of subjectively preferred income.

Let us assume that a monthly income of 800 zlotys is considered to be "hardly sufficient" by a respondent; 1,600 zlotys as "sufficient," 3,000 zlotys as "good" and 5,000 zlotys as "very good." The current disposable income of the household is 2,000 zlotys. This means that this respondent subjectively rates his or her income as higher than "sufficient," but not high enough to be classified as "good." In such a situation, the household's income is classified as "sufficient."

In this way, the author constructed a new ordinal variable called income preference. This variable places current disposable income on a scale of subjectively preferred income with five levels: "insufficient" (current disposable income less than "hardly sufficient"), "hardly sufficient" (current disposable income higher than "hardly sufficient" but lower than "sufficient"), "sufficient," "good" and "very good." An income preference described as "very good" means that the current disposable income of the household is above the "very good" level. In the example given above, the value of the income preference variable is "sufficient."

Subsequently, the ratio of preferred disposable income to current disposable income of the household was computed. The income preference ratio shows the disparity between the current income position of the household (actual disposable income) and its preferred income position. The disparity between subjectively preferred and current income stems from an implied attitude of the household head toward placing the household's disposable income above a level described as "bad" but below the "good" level. This is in line with a theory according to which the perception of income status is always relative, with regard to either one's neighbors or general consumption styles and saving patterns prevailing in society.

The analysis of the income preference ratio is conducted with respect to the age and gender of the household head. Then household savings from current disposable income are analyzed depending on the preferred income group to which a household belongs according to the income perception of the household head.

According to the 2004 Household Budget Surveys, 56\% of Poland's households are headed by men. The share of households run by women has grown in recent years from just over $30 \%$ to $44 \%$. This influences consumption profiles and savings because households headed by women differ in both average disposable income and income expectations. 
The disposable income of Polish households run by women is roughly a quarter lower than the average disposable income of households headed by men. This is the real economic basis of income expectations for the future. Women as household heads also have lower expectations as far as the subjectively preferred income of households is concerned.

Differences in income preferences between men and women are the most evident for income perceived as "good" and "very good." In the top income group, women prefer their disposable income to be about two-and-half times higher on average than the average disposable income of women in this income group. For men in the same top income group, expectations of preferred income are about three times higher on average than the average disposable income of men in this income group.

Figure 1. Preferred income vs. current disposable income according to income preference group in households run by women

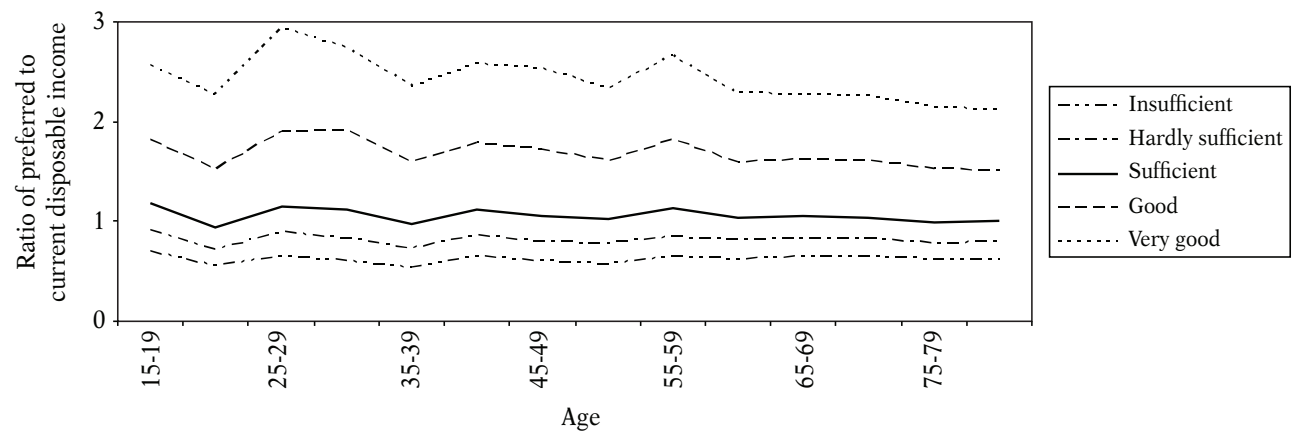

Source: Household Budget Surveys in 2004, Central Statistical Office, Warsaw, Poland.

When current disposable incomes are low ("sufficient," "hardly sufficient" or "insufficient"), the average income preferences of men and women are similar (the relevant curves are at almost the same level in Figures 1 and 2). The income preferences of women and men differ significantly according to age group, with the greatest discrepancy in very young households.

Women (Figure 1) would prefer their incomes to be no higher than three times their current disposable income. Income preferences among women peak in three age groups: young households in the 25-34 age group, households in the 40-44 age group, and households in the 55-59 age group. The first peak reflects the growing aspirations of young Polish women, most of whom are economically active and well educated. Women in the two other age groups, 40-44 and 55-59, either started or continued their professional careers under the market transition that began in Poland in 1990. They have succeeded in the new economic environment and have high expectations of future income. Generally, they do not retire early (even though early retirement is an option for women aged 50/55 years in Poland) to avoid a sharp decline in their income level. Women who have not succeeded economically and socially choose 
early retirement more often. Quite rationally, they also express lower income expectations.

Figure 2. Preferred income vs. current disposable income according to income preference group in households run by men

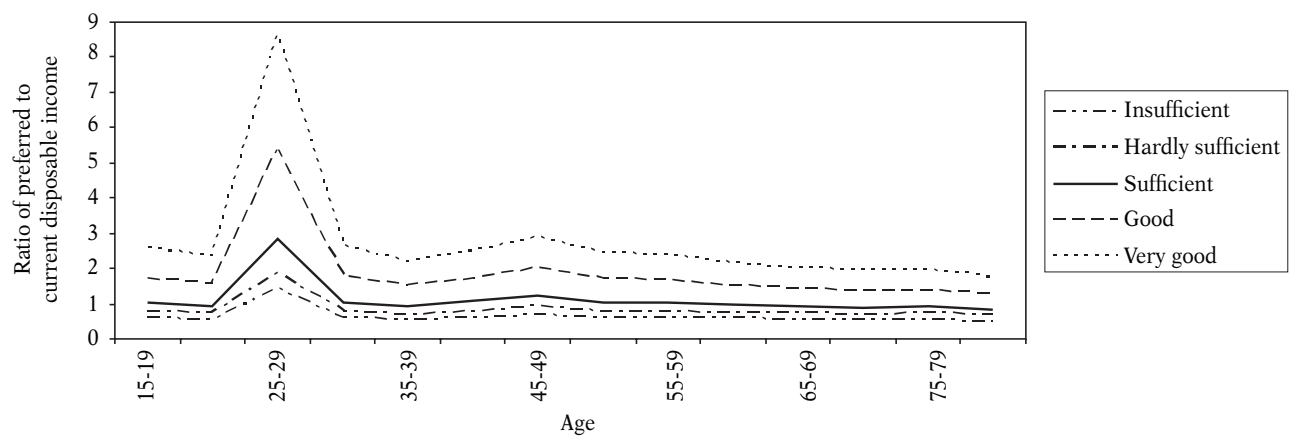

Source: Household Budget Surveys in 2004, Central Statistical Office, Warsaw, Poland.

The least affluent households headed by women declare that an income accounting for $60 \%$ of their current income would be "insufficient" for their families. This is a standard behavior that reflects a psychological need to defend one's meager income status by stating that one's current income is far from the worst possible income position. Similar declarations have been made by the least affluent households headed by men, with the exception of households formed by very young men (Figure 2).

Income preferences in individual age groups for households run by men yield a more diversified picture (Figure 2). Young men (25-29 years old) express "very high" income preferences. Wealthy households headed by men prefer their income to be more than eight times higher than their current disposable income. Income expectations are much higher in this age group at all income levels.

Unlike poorer women's households, poorer households formed by men aged 25-29 declare that their current disposable income is less than "insufficient" or "hardly sufficient." The income preference ratio, or the relation of preferred to current income, is larger than 1 for men's households in the 25-29 age group and smaller than 1 in women's households in the same age group.

In other age groups among men and in all women's households, "insufficient" and "hardly sufficient" incomes are invariably above the subjectively preferred levels, while "good" and "very good" current disposable incomes are always below the preferred income levels (Figures 1 and 2).

There is no second peak of subjectively preferred income for men; though men aged 45-49 also express high income preferences - at a level similar to the highest level of income preferences among women (about three times their current income). 
Except for one or two peaks of subjectively preferred income, most profiles of the preferred-to-current disposable income ratio are quite flat according to age group. Preferred income expectations are much higher in groups with higher current disposable incomes. It will be shown later how these expectations of preferred income affect the saving patterns of households.

\section{Household saving according to income preferences and demographic characteristics}

Savings are usually made by households, not individuals. Even if there is only one earning member of a family, the savings, or unspent income, are the outcome of all the family needs and available assets. Therefore, the saving profiles of households depend mainly on the socio-demographic features of the household such as the size of the household, gender, age of all family members, number of children, employability, retirement patterns, pension availability, and bequests received and expected. Other crucial determinants of savings are the level of current income and the expected growth of disposable income.

The above analysis shows that household income expectations depend on the gender and age of the household head as well as the perception of their actual income. This is illustrated by arranging households' current disposable incomes according to preferred income group. Current disposable income is perceived as "very good" or "good," "sufficient," "hardly sufficient" or "insufficient."

Figure 3 shows the saving rates for current disposable income in households classified by the gender of the household head and group of subjectively preferred household income. Household savings depend on current disposable income and the preferred income group to which a household belongs according to the income perceptions of the household head.

Figure 3. Household saving rates with respect to the gender of the household head and group of preferred income

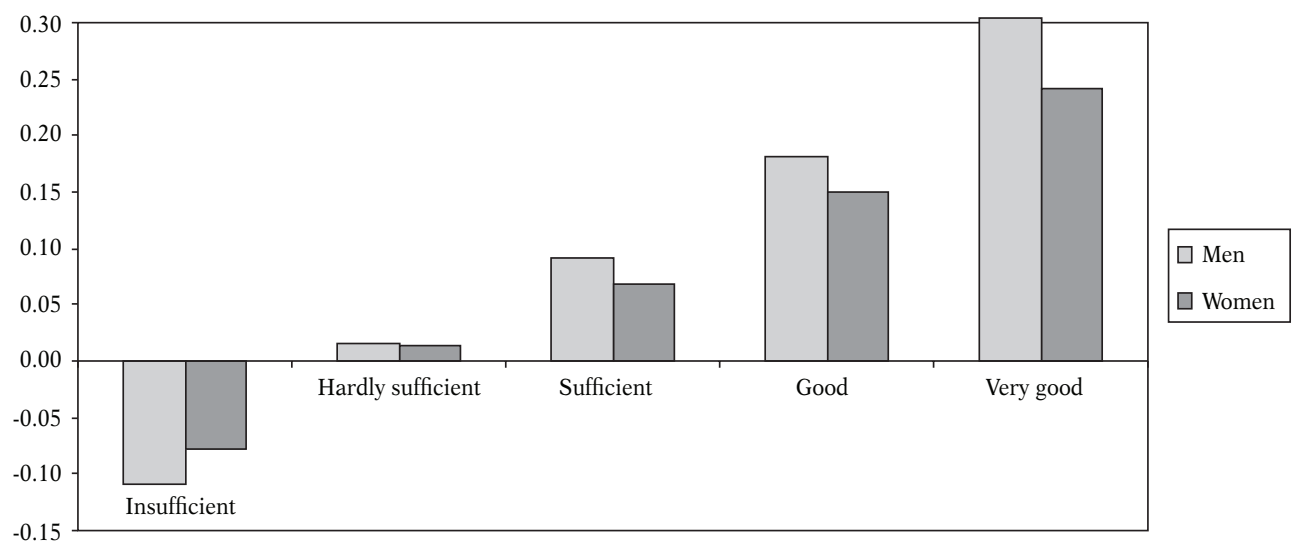

Source: Household Budget Surveys in 2004, Central Statistical Office, Warsaw, Poland. 
Savings are lower in households run by women with the exception of negative savings in the lowest income group in which men incur more loans and debts. Women perceiving their incomes as "insufficient" are more cautious in incurring debt. Their borrowing constraints might be more severe than the borrowing constraints of men. Generally, women as household heads are less eager than men to incur debt for their households. Differences in saving rates between women and men mainly arise from the lower levels of disposable income in households headed by women than in households headed by men.

In households whose current disposable incomes are perceived as "very good," saving rates are the highest. Interestingly, however, households that describe their income as "hardly sufficient" also report savings. Even though the real incomes of these households are roughly $25 \%$ lower than the average for all households [Pęczkowski, 2006], these households evidently save for precautionary reasons.

The saving rates of the most educated people are generally higher than average. The same pattern was observed in Poland prior to 2001, while later, during the economic slowdown of 2001-2002, people with tertiary education lost their leading position in terms of savings, though their incomes were still the highest among all households [Liberda, 2005]. Households headed by people with tertiary education seem to protect their consumption levels at the cost of saving, which is especially visible in lower income groups.

Figure 4. The saving rates of households with respect to the household head's education and preferred income group

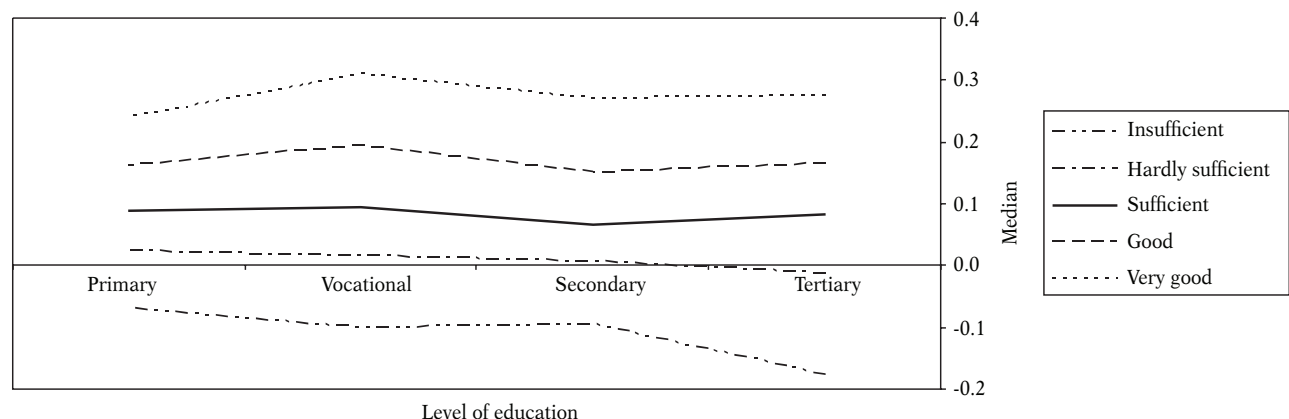

Source: Household Budget Surveys in 2004, Central Statistical Office, Warsaw, Poland.

People with a vocational education save the most. Prior to 2001, this group reported the second highest saving rates, after savers with tertiary education. Interestingly, the incomes of savers with a vocational education are close to the average for all households, being higher than average only in the "very good" income group. The saving motives of these people may be driven by a "demonstration effect," as well as the new opportunities that emerged after Poland's transition to a market economy. 
The saving profiles of households run by women are correlated with their current disposable income and their perceptions of preferred income. Figure 5 shows that the saving rates are the highest in households with "good" and "very good" incomes, while being negative in households with "insufficient" incomes.

Because subjectively preferred incomes are higher than current incomes in all groups with income higher than "sufficient" (Figure 1), it can be concluded that saving is positively related to income preferences in these income groups. Only when incomes fall below the "hardly sufficient" level are savings negative and negatively related to preferred incomes, which are lower than current disposable income in these groups (income preference ratio below 1).

Figure 5. Saving rates according to the age of the household head and group of preferred income in households run by women

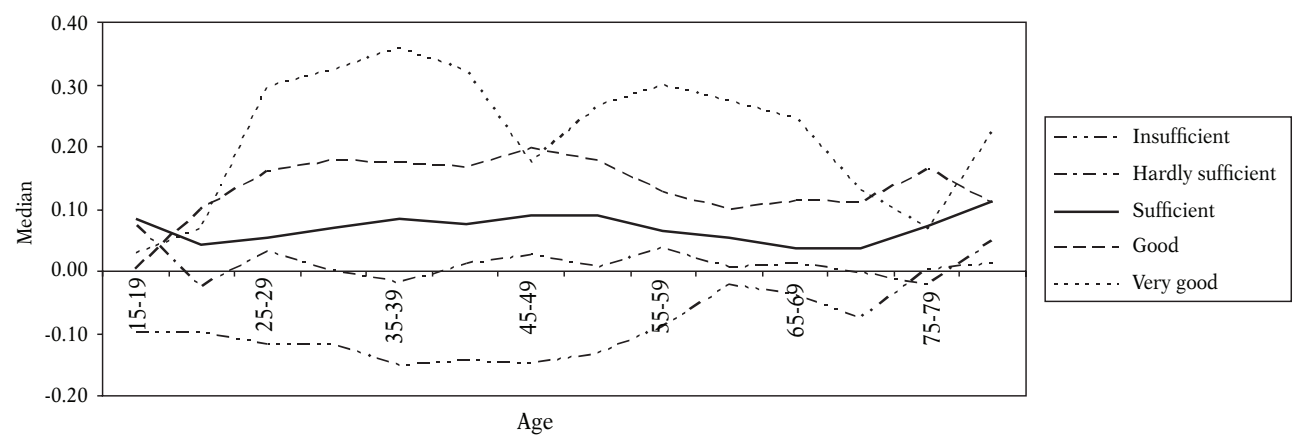

Source: Household Budget Surveys in 2004, Central Statistical Office, Warsaw, Poland.

The saving rates for women show two long peaks in the highest income group and a bottom peak in the low income group. Women between 25 and 44 years of age save according to their income status and income expectations (saving a third of their income in the highest income group and around onesixth in the case of incomes perceived as "good"). The second peak of savings in the 50-64 age group is lower but also related to this group's high current and preferred incomes.

The lowest saving rates are in low income groups among women aged 35-50. This is related to the highest family expenditures on children in this age group. 
Figure 6. Saving rates according to the age of the household head and group of preferred income in households run by men

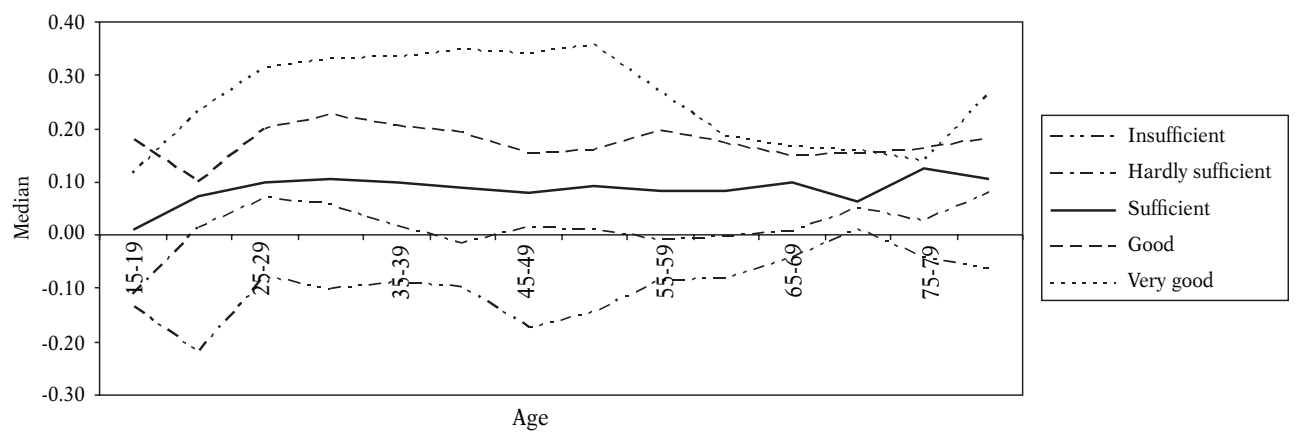

Source: Household Budget Surveys in 2004, Central Statistical Office, Warsaw, Poland.

Men as household heads display a more stable rising trend in saving rates from 25 to 54 years (Figure 6). Later their savings tend to fall at the age of around 60, which is when the average Polish man retires. This is in contrast to the exorbitant income expectations of young men and the relatively flat profile of income preferences among middle-aged and old men (Figure 2). It looks that the savings of men are more closely related to their current disposable income than to preferred income. "Very high" preferred incomes may be a matter of aspirations and ambition rather than real family needs. The income preferences of women are more related to actual household requirements.

The overall saving profile of all households (Figure 7) is closer to the profile of households headed by men than those run by women. Combining women's and men's income preferences has "smoothed" saving rates for the lowest and the highest income groups. The mid-income groups show very smooth saving profiles for both men and women as well as the average for all households.

Figure 7. Saving rates according to the age of the household head and preferred income group for all households

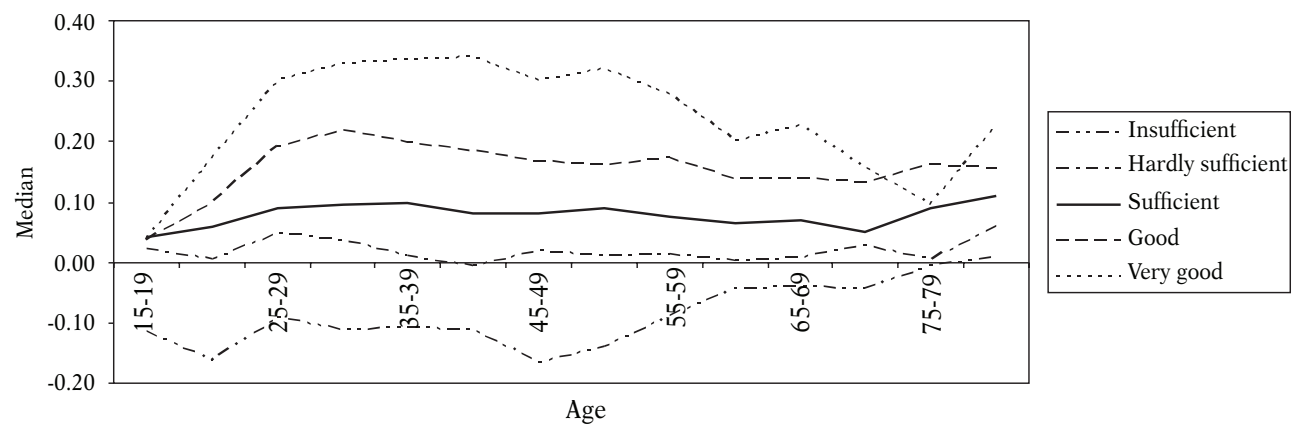

Source: Household Budget Surveys in 2004, Central Statistical Office, Warsaw, Poland. 
The average saving rate for all households was $6.6 \%$ in 2004, with 5\% for households run by women and around $8 \%$ for those run by men. Of special note is the existence of positive savings in households with incomes perceived as "hardly sufficient."

Overall, household savings measured in individual income preference groups are influenced by both current and preferred incomes. In income groups where income is higher than "hardly sufficient," savings are positively related to current disposable incomes. When current disposable incomes fall below the "hardly sufficient" level, savings are negative.

Savings are also positively related to income preferences in households with income higher than "sufficient" as subjectively preferred incomes are always declared above the current income levels in these income groups (Figures 1 and 2). Only in the "insufficient" and "hardly sufficient" income groups are preferred incomes below the current disposable incomes. Savings relate positively to preferred incomes in households with "hardly sufficient" incomes, while relating negatively in households with "insufficient" incomes.

\section{Conclusions}

The above analysis shows that the subjectively preferred incomes of Polish households are much higher than their current disposable incomes, being the highest in young households. Income preferences depend on the gender and age of the household head. Women as household heads tend to have lower expectations with regard to preferred income than men.

Household savings are positively related to the levels of current disposable income above the "hardly sufficient" level. The ability to save suggests that the financial condition of Polish households may be better than it is subjectively perceived and declared by household heads. The income preferences of households (subjectively preferred incomes) positively influence household saving profiles, with the exception of households with "insufficient" incomes.

\section{References}

Baxter M., Jermann U.J., [1999], Household Production and the Excess Sensitivity of Consumption to Current Income, „American Economic Review”, Vol. 89, No. 4, 902-920.

Becker G.S., [1976], The Economic Approach to Human Behavior, The University of Chicago Press, Chicago.

Benartzi Sh., Thaler R., [1995], Myopic Loss Aversion and the Equity Premium Puzzle, „Quarterly Journal of Economics", 110 (1), 75-92.

Campbell J.Y., [1987], Does Saving Anticipate Declining Labor Income? An Alternative Test of the Permanent Income Hypothesis, „Econometrica”, 55, 1249-1273.

Carroll Ch., [1994], How Does Future Income Affect Current Consumption?, „Quarterly Journal of Economics", 109, 111-147.

Carroll Ch., [1997], Buffer Stock Saving and the Life-Cycle/Permanent Income Hypothesis, „Quarterly Journal of Economics", 112 (1), 1-55. 
Deaton A., [1991], Saving and Liquidity Constraints, „Econometrica”, 59 (5), 1221-1248.

Easterlin R.A., [2006], Life Cycle Happiness and Its Sources: Intersections of Psychology, Economics and Demography, „Journal of Economic Psychology”, 27, 4, 463-482.

Flavin M.A., [1981], The Adjustment of Consumption to Changing Expectations About Future Income, „Journal of Political Economy”, Vol. 81, No. 5, 974-1009.

Friedman M., [1957], A Theory of the Consumption Function, Princeton University Press.

Kahneman D., [2003], A Psychological Perspective on Economics, „American Economic Review, 93, No. 2, 162-168.

Kahneman D., Tversky A., [1979], Prospect Theory: An Analysis of Decision Under Risk, „Econometrica”, 47, 263-291.

Katona G., [1975], Psychological Economics, Elsevier, New York.

Keynes J.M., [1936], The General Theory of Employment, Interest and Money, Macmillan, London.

Kotlikoff L.J., [1989], What Determines Savings?, MIT Press, Cambridge.

Laibson D., [1997], Golden Eggs and Hyperbolic Discounting, „Quarterly Journal of Economics”, 112 (2), 443-477.

Lea S.E.G., Tarpy R.M., Webley P., [1987], The Individual in the Economy, Cambridge, Cambridge University Press.

Liberda B., [2005], How Much to Save to Behave Fair Towards Future Generations? Fair Savings in Poland, International Association for Research in Economic Psychology, (IAREP), Conference Proceedings, Prague.

Liberda B., Górecki B., Pęczkowski M., [2004], Saving From Permanent and Transitory Income: The Case of Polish Households, „Ekonomia” No. 14, 7-22.

Modigliani F., Brumberg R., [1954], Utility Analysis and the Consumption Function: An Interpretation of Cross-Section Data, in Post-Keynesian Economics, (ed.), K. Kurihara, Rutgers University Press New, Brunswick.

Pęczkowski M., [2006], Desired and Real Income of Polish Households, IAREP-SABE Congress, Paris.

Stark O., Wang Y.Q., Wang Y., [2005], Altruism: Evolution and a Repercussion, in Agarwal B., Vercelli A., Psychology, Rationality and Economic Behaviour, 2005, Palgrave, Macmillan, in association with the International Economic Association, 84-105.

Thaler R., Benartzi Sh., [2004], Save More Tomorrow: Using Behavioral Economics to Increase Employee Saving, „Journal of Political Economy”, 112 (1), S167-187.

Tyszka T., (ed.), [2004], Psychologia ekonomiczna, GWP, Gdańsk.

Warneryd K.-E., [1999], The Psychology of Saving: A Study on Economic Psychology, Elgar, Cheltenham UK.

\title{
INCOME PREFERENCES AND HOUSEHOLD SAVINGS
}

\author{
Sum mary
}

In this paper, the author deals with the saving profiles of households in relation to the perception of their subjectively preferred incomes. The author shows that household savings are influenced by a behavioral attitude concerning the evaluation of one's household income.

The variable used in the analysis of household behavior is an income preference ratio constructed by the author. This variable is computed as a ratio of the subjectively preferred income as declared by the household head to the current disposable income of the household. 
An analysis of the income preference ratio has been conducted with respect to the age and gender of the household head. It shows that women as heads of households generally have lower expectations regarding preferred income and that income preferences vary according to the age of the household head, being the highest at a young age.

Household savings are correlated with the level of current disposable income and income preferences. Positive household savings can even be observed among households with very low incomes. Savings rise significantly in households with income higher than "sufficient" and are very high in households with "good" and "very good" income.

The results of the analysis show that the income preferences of Polish households tend toward higher income levels than the actual level of disposable income. The propensity to save suggests that the financial condition of Polish households may be better than subjectively perceived and declared by the household head. The subjectively preferred incomes of households positively influence household saving profiles, with the exception of households with "insufficient" incomes.

The research is based on 2004 data for 32,000 households from Household Budget Surveys for Poland.

Keywords: income preferences, disposable income, household savings, saving profiles 